\title{
The effects of aqueous extracts of dried-pulverised or the fresh form of Talinum triagulare on the haematology and serum biochemistry of layers
}

\author{
Chinwe J. Aronu ${ }^{1 *}$, John O. A. Okoye ${ }^{3}$, John I. Ihedioha ${ }^{3}$, \\ Benjamin N. Marire ${ }^{1,4}$, and Silvanus M. Anika ${ }^{2}$ \\ ${ }^{I}$ Department of Animal Health and Production, Faculty of Veterinary Medicine, University of Nigeria, Nsukka, \\ Enugu State, Nigeria \\ ${ }^{2}$ Department of Physiology and Pharmacology, Faculty of Veterinary Medicine, University of Nigeria, Nsukka, \\ Enugu State, Nigeria \\ ${ }^{3}$ Department of Pathology and Microbiology, Faculty of Veterinary Medicine, University of Nigeria, Nsukka, \\ Enugu State, Nigeria \\ ${ }^{4}$ Department of Animal Science, Faculty of Agriculture, Enugu State University of Science and Technology, \\ Agbani, Nigeria
}

ARONU, C. J., J. O. A. OKOYE, JOHN I. IHEDIOHA, B. N. MARIRE, S. M. ANIKA: The effects of aqueous extracts of dried-pulverised or the fresh form of Talinum triagulare on the haematology and serum biochemistry of layers. Vet. arhiv 88, 687-707, 2018.

\section{ABSTRACT}

The study investigated the effect of graded doses of aqueous extract of Talinum triangulare on the haematology and serum biochemistry of laying hens. Two hundred and ten pullets, procured at 18 weeks of age, were used for the study. They were randomly assigned to seven study groups ( $\mathrm{LAT}_{1}, \mathrm{LAT}_{2}, \mathrm{LAT}_{3}, \mathrm{LBT}_{1}$, $\mathrm{LBT}_{2}, \mathrm{LBT}_{3}$, and LC). Each study group was replicated thrice and each replicate housed ten pullets. Extracts obtained from a dried pulverized form of T. triangulare were given at $62.5,250$, and $1000 \mathrm{mg} / \mathrm{L}$ doses in their drinking water for treatment groups $\mathrm{LAT}_{1} \mathrm{LAT}_{2}$ and $\mathrm{LAT}_{3,}$ respectively, while extracts obtained from freshly harvested Talinum triangulare were administered at $62.5,250$, and $1000 \mathrm{mg} / \mathrm{L}$ doses to groups $\mathrm{LBT}_{1}$, $\mathrm{LBT}_{2}$, and $\mathrm{LBT}_{3}$, also in their drinking water. Pullets in the LC group served as the untreated control and received no extract. Haematology and serum biochemistry were determined at two-month intervals within the 8 month period of administration of the extracts, following standard procedures. The results showed that there were no significant $(\mathrm{P}>0.05)$ variations amongst all the study groups in their packed cell volume, red blood cell counts, haemoglobin concentration, total leukocyte counts, serum alanine aminotransferase and aspartate aminotransterase activities, and total proteins. The serum high density lipoprotein concentration was higher and serum low density lipoprotein concentration was lower significantly $(\mathrm{P}<0.05)$ in group $\mathrm{LAT}_{3}$, when compared

*Corresponding author:

Aronu Chinwe Justina (DVM, MSc, PhD, FCVSN), Department of Animal Health and Production, Faculty of Veterinary Medicine, University of Nigeria, Nsukka, Enugu State, Nigeria, Phone: +234 703062 7496; E-mail: chinwe.aronu@unn.edu.ng 
C. J. Aronu et al.: Effect of Talinum triangulare on haematology and serum biochemistry of layers

to the others, especially in months four and eight of the experiment. It was concluded that treatment with $T$. triangulare had no adverse effect on the health and production status of the layers, but had positive effects on the serum lipid profile. Dried-pulverised Talinum triangulare at the dose of $1000 \mathrm{mg} / \mathrm{L}$ was recommended for use as a phytobiotic supplement with anti-lipidemic properties for a healthy productive life in laying hens.

Key words: Talinum triangulare; haematology; serum biochemistry; health; phytobiotic; laying hens

\section{Introduction}

Recently livestock production worldwide is growing rapidly as a result of the increasing demand for animal products. Food and Agricultural Organisation (FAO) projections suggested that global meat production and consumption will rise from 233 million tonnes in the year 2000 to 300 million tonnes in 2020, and milk from 568 to 700 million tonnes over the same period. Egg production will also increase by $30 \%$. These data indicate a massive increase in the animal protein supply needed to satisfy the human population growth (ANON, 2014). In order to meet the challenge of increasing demand for animal products, poultry research centres will definitely be of great assistance to address the issues relating to nutrition and disease control that challenge success in poultry production.

The increasing cost and decreasing supply of traditional feedstuffs in developing countries of the world, pose a constraint to the future expansion of poultry industry (ANON., 2014). Feed is the most important input for poultry production; therefore, the availability of low-priced, high quality feeds and feed ingredients is critical for the expansion of the poultry industry (ANON., 2014). Consequently, there is a continual need to evaluate new or different sources of ingredients, and to re-examine the more commonly used ingredients.

Protein and energy components represent more than 90 per cent of the total nutrient requirements of poultry rations (MENGESHA, 2012). The high cost of grains is known to be responsible for the rising cost of poultry products (ANON., 2008). Moreover, the conventional protein feedstuffs for poultry, such as soya bean, groundnut cake and fish meal, are not only expensive but are also scarce.

Talinum triangulare (waterleaf plant), belongs to the Purslane family (Portulacacae). It is a leafy vegetable found in West Africa, the West Indies, and South America (AKACHUKU and FAWUSI, 1995). The leaves and tender stems of the waterleaf are consumed as a vegetable or as a constituent of sauces in most parts of Nigeria. Waterleaf grows spontaneously during the rainy season, and it is common in a variety of habitats including roadsides, open fields and abandoned agricultural land (SCHIPPERS, 2009). Although it is extensively consumed, until recently not much was known about the nutritive value of $T$. triangulare (KWENIN et al, 2011; CHANDRA et al, 2016). There is also growing evidence that apart from nutrients, other components of food of plant origin, 


\section{J. Aronu et al.: Effect of Talinum triangulare on haematology and serum biochemistry of layers}

(phytochemicals) may play an integral role in the link between food and health (PEM and JEEWON, 2015).

The present study focused on the effect of giving laying hens drinking water supplemented with aqueous extract of $T$. triangulare on their health parameters, and sought to verify some of the claims made by earlier workers. Specifically, the study investigated the effects of administration of graded doses of aqueous extract of driedpulverised and freshly harvested Talinum triangulare on the haematology and serum biochemistry of laying hens.

\section{Materials and methods}

Experimental plant. The Talinum triangulare used for the study was sourced from a vegetable garden attached to the Students' Research Farm of the Department of Animal Health and Production, University of Nigeria, Nsukka. Leaves and succulent shoots of $T$. triangulare were harvested and used for the study.

For preparation of the dried-pulverised sample, the harvested parts were air dried and pulverized using an electric grinding machine (SFP-2210, Sonik, Japan) to obtain a powdered form. Then, $500 \mathrm{~g}$ of the dried-pulverised powder was extracted using 1400 mLof distilled water following the cold maceration procedure for a period of 48 hours. Thereafter it was stirred for two hours and then sieved through a domestic sieve cloth. The filtrate was collected and stored in the refrigerator for use. A given quantity of the filtrate from the extraction was completely dried under vacuum and weighed; the residue was used to determine the percentage yield of the sample upon which the dosage was determined (OTTAH et al., 2012).

In order to prepare the extract from freshly harvested $T$. triangulare, the harvested leaves and succulent shoots were washed, drained and cut into small pieces. They were then ground into a smooth paste with a grinding machine (SFP-2210, Sonik, Japan). The ground paste was left to stand for 48 hours and stirred for two hours for complete mixing. Thereafter, it was filtered with a domestic sieve cloth; the filtrate was collected and then kept in a refrigerator for the experiment (OTTAH et al., 2012). The percentage yield and dosage were determined as stated above. Extracts from both the dried-pulverised and the freshly harvested samples were prepared weekly, and percentage yield, concentration and dosage were re-established each time to ensure consistency.

Experimental animals. Two hundred and ten Isa Brown pullets, procured at pointof-lay (18 weeks of age) from Kosy Veterinary Consult Enugu, Nigeria, in August 2015 were used for the study. They were housed at the Students' Research Demonstration Farm of the Department of Animal Health and Production, University of Nigeria, Nsukka. They were acclimatised for one month on deep litter, during which water and standard 
pullet feed (Top Growers Feed ${ }^{\circledR}$, Premier Feeds Company Ltd, Ibadan, Nigeria) were provided ad libitum. Records from the source of the birds showed that the following standard prescribed vaccinations had been administered to the birds: Newcastle disease (Intra ocular, LaSota and Komarov), Gumboro and Fowl Pox. Also, anti-coccidial drugs were administered following standard protocols. All the experimental birds were treated uniformly in terms of feeding and other management practices, in accordance with standard production procedures.

The study complied with the University of Nigeria's standard ethical/humane practices for the use of animals in research. The animal experimental protocol was approved by the Experimental Animal Ethics Committee of the Faculty of Veterinary Medicine, University of Nigeria, Nsukka and was in compliance with the Federation of European Laboratory Animal Science Association and the European Community Council Directive of November 24, 1986 (86/609/EEC).

Experimental design. After acclimatization, the 210 pullets were randomly assigned to three groups (A, B, and C) made up of 90 in group A, 90 in group B and 30 in group C. Groups $A$ and $B$ respectively were further subdivided into three treatment sub-groups of 30 each (LA1, LA2 and LA3 for group A, and LB1, LB2 and LB3 for group B). Group C which served as the un-supplemented control had only one treatment group. This resulted in a total of seven sub-groups labelled, $\mathrm{LAT}_{1}, \mathrm{LAT}_{2}, \mathrm{LAT}_{3}, \mathrm{LBT}_{1}, \mathrm{LBT}_{2}, \mathrm{LBT}_{3}$, and LC, each made up of 30 birds. The sub-groups were further divided into three replicates which accommodated 10 pullets per replicate. Replicates in each group were given the same group-specific treatments.

After grouping the birds, baseline (Month 0) values for all the haematology and serum biochemistry parameters were evaluated from six birds selected at random from each group. The T. triangulare extracts were administered in drinking water as follows: Groups LAT LAT $_{2}$ and LAT 3 were given $62.5,250$ and $1000 \mathrm{mg} / \mathrm{L}$ of the extracts of the dried-pulverised sample, while Groups $\mathrm{LBT}_{1}, \mathrm{LBT}_{2}$ and $\mathrm{LBT}_{3}$ were given 62.5, 250 and $1000 \mathrm{mg} / \mathrm{L}$ of the extracts of the freshly harvested sample. The Group C birds were given plain drinking water and served as the control. The group-specific drinking waters were provided ad libitum. The pullet feed was gradually changed to a standard layer diet (Top Layer Feed ${ }^{\circledR}$, Premier Feeds Company Ltd, Ibadan, Nigeria). The feed was provided ad libitum. The extracts were administered to the specific groups for the 8 months of the experimental period. Blood samples were collected from six birds selected at random from each group on day 60 (Month 2), day 120 (Month 4), day 180 (Month 6) and day 240 (Month 8) for evaluation of the haematology and serum biochemistry parameters.

Parameters analysed and laboratory procedures. The haematological parameters evaluated were packed cell volume (PCV), red blood cell (RBC) count, haemoglobin 
concentration $(\mathrm{HbC})$, and total white blood cell (TWBC) count, while the serum biochemistry parameters assayed were total cholesterol (TChol), triacylglycerol (TAG), high density lipoprotein cholesterol (HDL-C), low density lipoprotein cholesterol (LDL-C), alanine aminotransferase (ALT) activity, aspartate aminotransferase (AST) activity and total protein (TP).

Blood sample collection. After proper restraint, $5 \mathrm{~mL}$ of blood was collected from the right jugular vein of each of the birds, using a $5 \mathrm{~mL}$ hypodermic needle and syringe. Two millilitres of the blood collected was quickly and gently dispensed into a labelled 5-ml plastic sample bottle (Micropoint Diagnostics, England) containing $2 \mathrm{mg}$ of NaEDTA. The sample bottle was gently rocked to mix the blood with Na-EDTA to prevent coagulation. The haematological determinations commenced immediately upon sample collection for each sample, to avoid artifactual changes (IHEDIOHA et al., 2008). The remaining $3 \mathrm{~mL}$ was dispensed into a pre-labelled plain test tube (containing no anticoagulant) (Surgifriend Medical, England). The tube was kept in a slanted position, and thereafter centrifuged for 10 minutes at $3000 \mathrm{~g}$; the supernatant (serum) was decanted and aspirated into a labelled 2-ml capacity sample bottle for serum biochemistry determinations.

Haematological determinations. The packed cell volume (PCV) was determined by the microhaematocrit method (THRALL and WEISER, 2002), using a Haematospin $1400^{\circledR}$ microhaematocrit centrifuge and a Hawksley Microhaematocrit Reader ${ }^{\circledR}$ (Hawksley \& Sons Ltd. West Sussex, UK). The haemoglobin concentration was determined by the cyanomethaemoglobin method (HIGGINS et al., 2003), using a CHEM5V3 semiautomated blood analyzer (Erba Diagnostics, Mannheim Germany). The red blood cell (RBC) and total white blood cell (WBC) counts were done manually following the haemocytometer method, using Natt and Herrick's solution as the diluting fluid (CAMPBELL, 1994), improved Neubauer counting chamber (Hawksley \& Sons Ltd. West Sussex, UK) and a light microscope (Leica Gallen, New York, USA).

Serum lipid profile evaluation. The serum lipid profile was evaluated using commercially available test kits manufactured by Quimica Clinica Aplicada (QCA), Spain. The serum TChol determination was based on the enzymatic colorimetric method (ALLAIN et al., 1974), and was done using the QCA total cholesterol working reagent and assayed using a CHEM5V3 semi-automated blood analyzer (Erba Diagnostics, Mannheim Germany). The serum TAG level determination was based on the glycerol-phosphate oxidase method (BUCCOLO and DAVID, 1973), and was done using the QCA triglyceride working reagent and assayed using a CHEM5V3 semi-automated blood analyzer (Erba Diagnostics, Mannheim Germany). The serum HDL-C was determined by the dextran sulphate magnesium (II) precipitation method (ALBERS et al., 1978), and was done using 
the QCA HDL-C precipitant reagent and the supernatant was assayed after the precipitation using a CHEM5V3 semi-automated blood analyzer (Erba Diagnostics, Mannheim Germany). The serum low density lipoprotein cholesterol (LDL-C) was calculated using Friedewald's formular (FRIEDEWALD et al., 1972; WARNICK et al., 1990).

Assay of serum enzyme activity and total proteins. Serum enzyme activity and total protein levels were also assayed using commercially available test kits manufactured by Quimica Clinica Aplicada (QCA), Spain. The serum ALT and AST activities were assayed based on the Reitman-Frankel colorimetric method (REITMAN and FRANKEL, 1957), using the QCA ALT and AST working reagents and read with a CHEM5V3 semiautomated blood analyzer (Erba Diagnostics, Mannheim Germany), while the serum TP levels were assayed based on the Biuret method (LUBRAN, 1978), using the QCA TP working reagent and read with a CHEM5V3 semi-automated blood analyzer (Erba Diagnostics, Mannheim Germany),

Data analysis. Data on hematology and serum biochemistry were subjected to one way analysis of variance (ANOVA), using the SPSS version 15.0 for Windows. Variant means were separated using the least significant difference (LSD) method. Significance was accepted at $\mathrm{P}<0.05$.

\section{Results}

Haematological values. There were slight decreases in the PCV, RBC count, haemoglobin concentration and TWBC counts in all groups from Month 0 to Month 8 as the experiment progressed, but there were no significant variations $(\mathrm{P}>0.05)$ across the groups for all these haematological values throughout the experimental period (Figs 1, $2,3$ and 4$)$. 
C. J. Aronu et al.: Effect of Talinum triangulare on haematology and serum biochemistry of layers

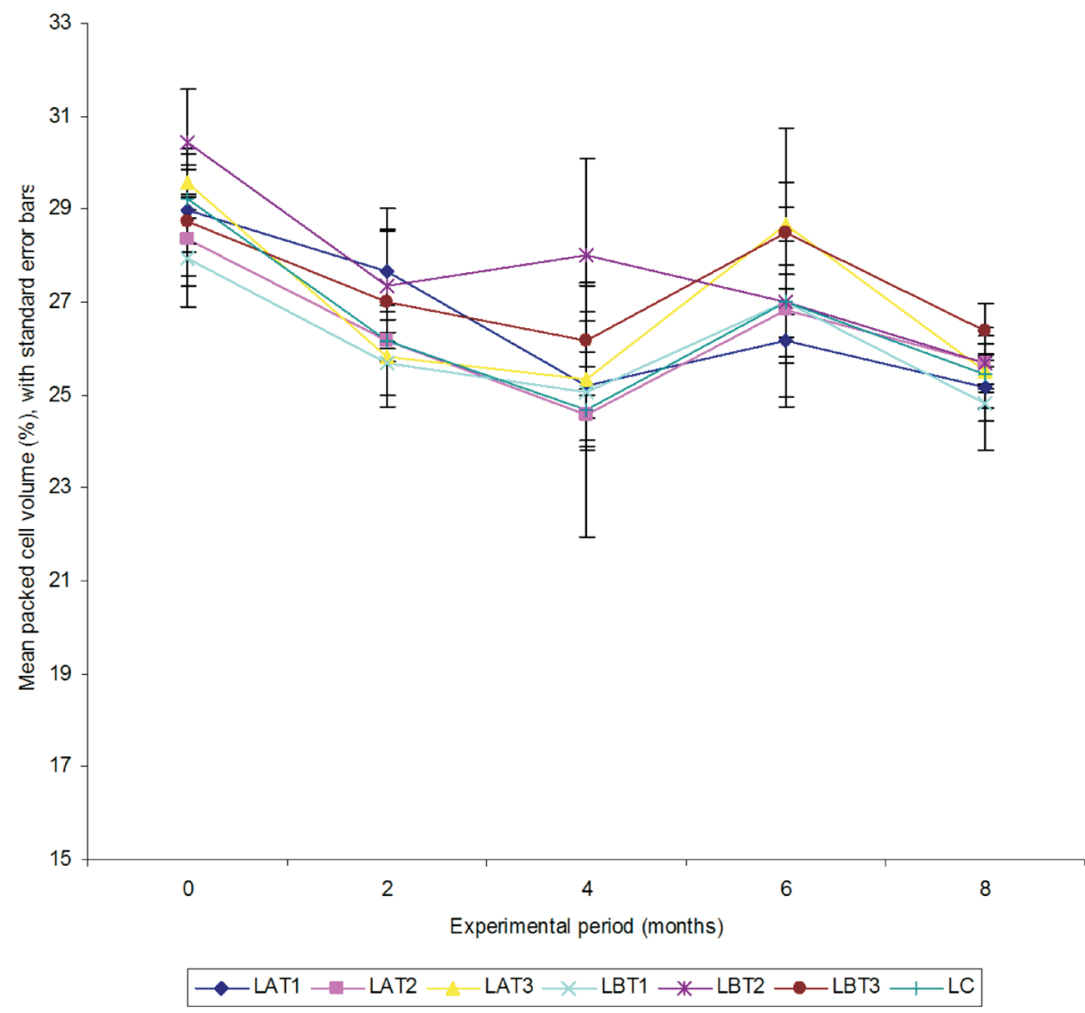

Fig. 1. The packed cell volume of groups* of laying hens given varied doses of extracts of dried-pulverised and fresh Talinum triangulare in drinking water. * Groups and their treatments: LAT1, LAT2 and LAT3 were given $62.5,250$ and $1000 \mathrm{mg} / \mathrm{L}$ of extract of dried-pulverised $T$. triangulare, respectively; LBT1, LBT2 and LBT3 were given $62.5,250$ and $1000 \mathrm{mg} / \mathrm{L}$ of extract of freshly harvested $T$. triangulare, respectively; while LC was the untreated control given plain drinking water only. 
C. J. Aronu et al.: Effect of Talinum triangulare on haematology and serum biochemistry of layers

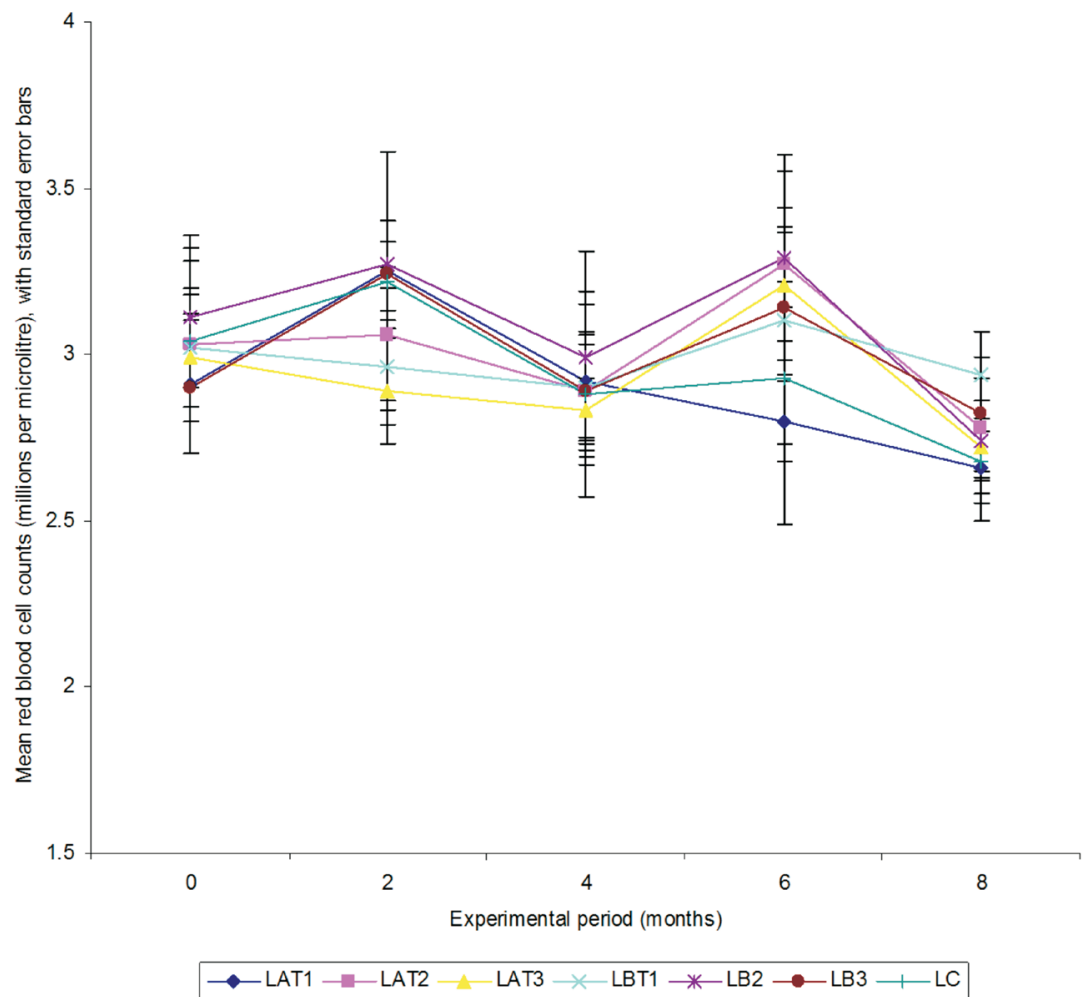

Fig. 2. The red blood cell count of groups* of laying hens given varied doses of extracts of dried-pulverised and fresh Talinum triangulare in drinking water. ${ }^{*}$ Groups and their treatments: LAT1, LAT2 and LAT3 were given 62.5, 250 and $1000 \mathrm{mg} / \mathrm{L}$ of extract of dried-pulverised $T$. triangulare, respectively; LBT1, LBT2 and LBT3 were given $62.5,250$ and $1000 \mathrm{mg} / \mathrm{L}$ of extract of freshly harvested T. triangulare, respectively; while LC was the untreated control given plain drinking water only. 


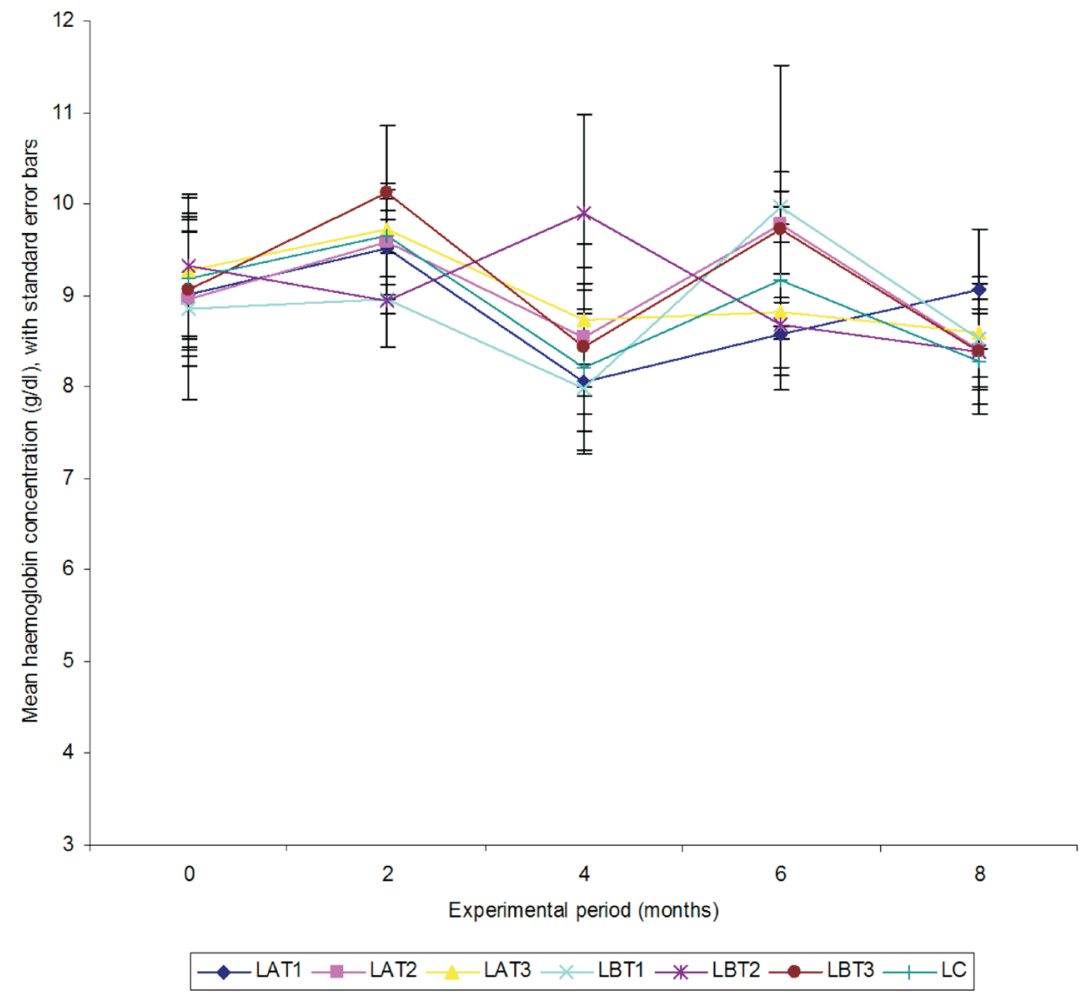

Fig. 3. The haemoglobin concentration of groups* of laying hens given varied doses of extracts of dried-pulverised and fresh Talinum triangulare in drinking water. * Groups and their treatments: LAT1, LAT2 and LAT3 were given $62.5,250$ and $1000 \mathrm{mg} / \mathrm{L}$ of extract of dried-pulverised $T$. triangulare, respectively; LBT1, LBT2 and LBT3 were given $62.5,250$ and $1000 \mathrm{mg} / \mathrm{L}$ of extract of freshly harvested $T$. triangulare, respectively; while LC was the untreated control given plain drinking water only. 
C. J. Aronu et al.: Effect of Talinum triangulare on haematology and serum biochemistry of layers

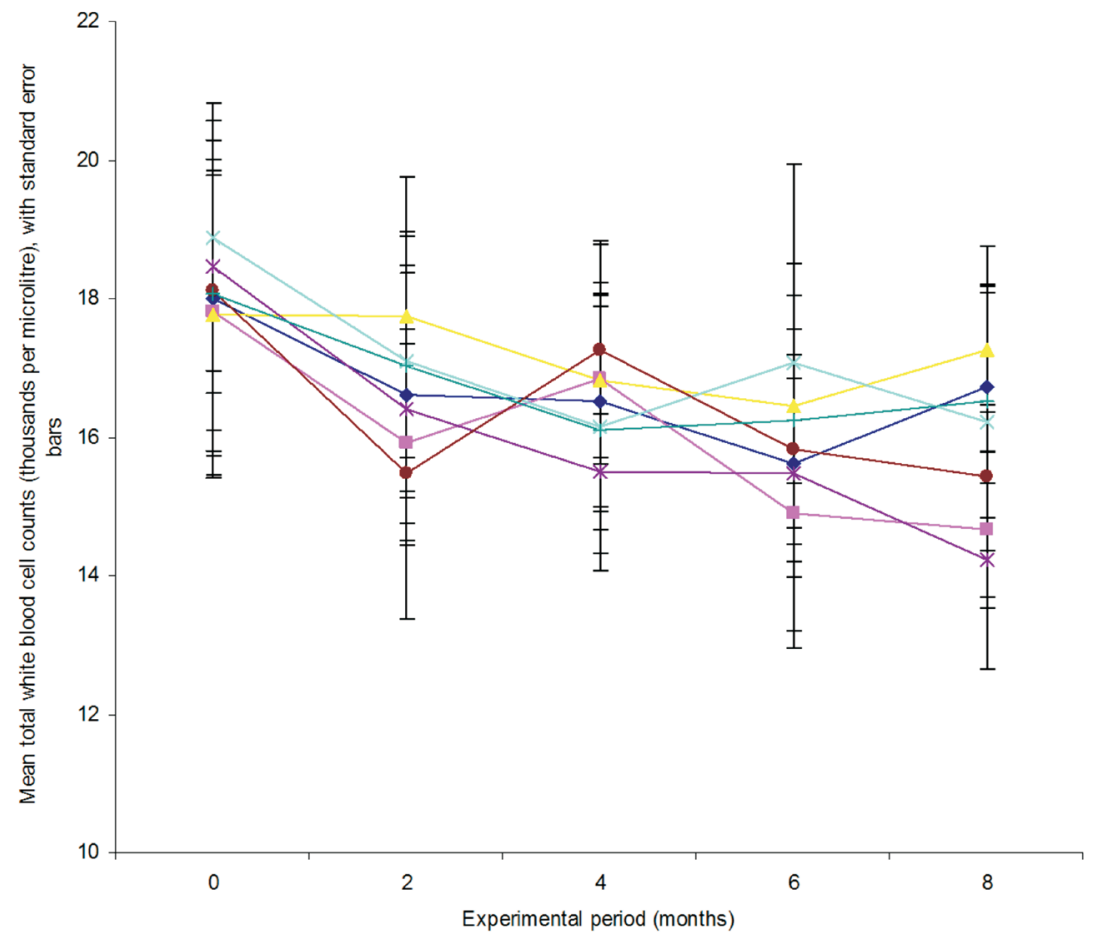

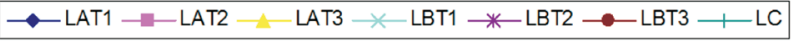

Fig. 4. The total white blood cell count of groups* of laying hens given varied doses of extracts of dried-pulverised and fresh Talinum triangulare in drinking water. * Groups and their treatments: LAT1, LAT2 and LAT3 were given 62.5, 250 and $1000 \mathrm{mg} / \mathrm{L}$ of extract of dried-pulverised $T$. triangulare, respectively; LBT1, LBT2 and LBT3 were given 62.5, 250 and $1000 \mathrm{mg} / \mathrm{L}$ of extract of freshly harvested $T$. triangulare, respectively; while LC was the untreated control given plain drinking water only. 
C. J. Aronu et al.: Effect of Talinum triangulare on haematology and serum biochemistry of layers

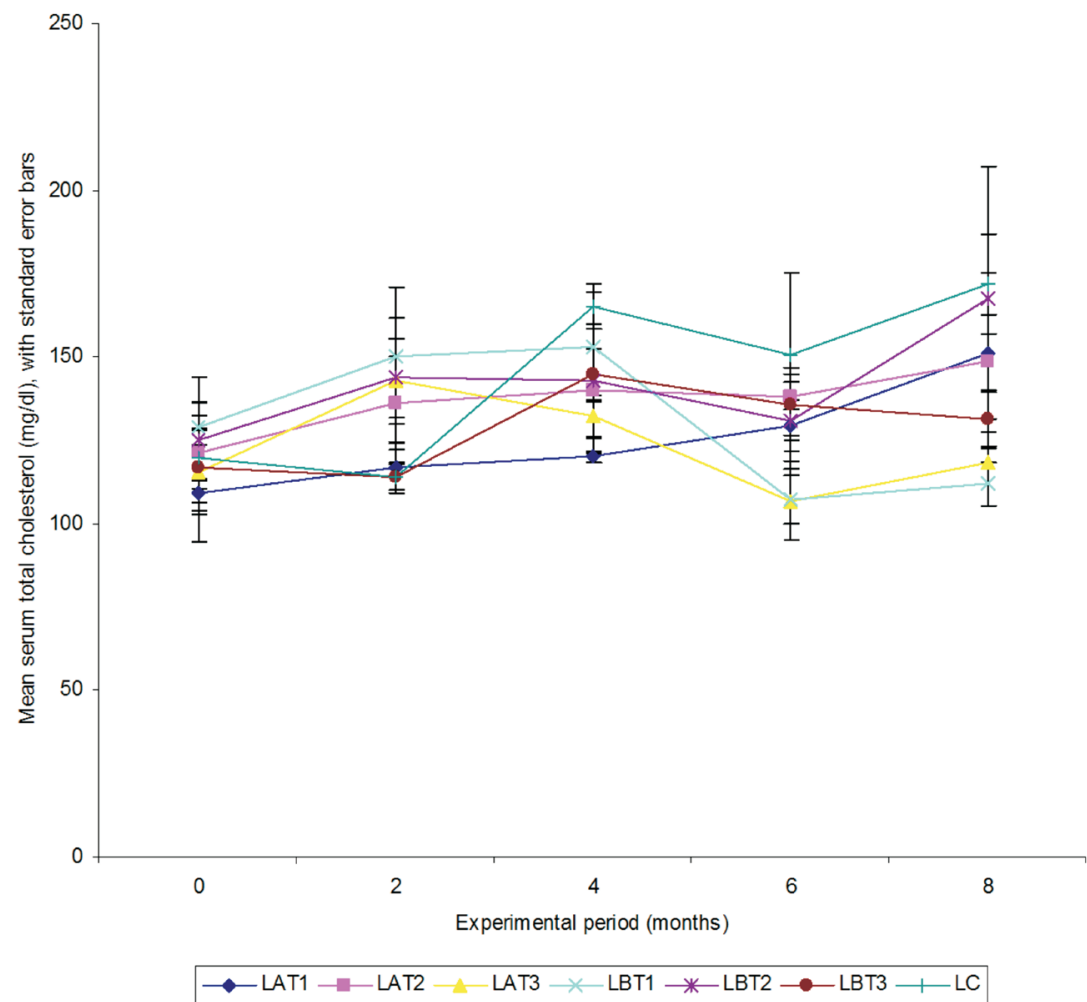

Fig. 5. The serum total cholesterol levels of groups* of laying hens given varied doses of extracts of dried-pulverised and fresh Talinum triangulare in drinking water. * Groups and their treatments: LAT1, LAT2 and LAT3 were given $62.5,250$ and $1000 \mathrm{mg} / \mathrm{L}$ of extract of driedpulverised T. triangulare, respectively; LBT1, LBT2 and LBT3 were given 62.5, 250 and 1000 $\mathrm{mg} / \mathrm{L}$ of extract of freshly harvested $T$. triangulare, respectively; while LC was the untreated control given plain drinking water only.

Serum biochemistry. The serum total cholesterol of all the groups generally increased with the age of the birds (as the experimental time period progressed from month 0 to month 8). There were no significant variations ( $\mathrm{P}>0.05)$ across the groups on Month 0 and 2, but at month 4 of the experiment, the total serum cholesterol levels of the group $\mathrm{LAT}_{1}$ layers was significantly lower $(\mathrm{P}<0.05)$ than that of the LC control birds (Fig. 5). At Month 6, there were no significant variations across the groups, but at Month 8 of the experiment the serum total cholesterol of the $\mathrm{LAT}_{3}$ and $\mathrm{LBT}_{1}$ groups was significantly lower $(\mathrm{P}<0.05)$ than that of the LC control group (Fig. 5). 
C. J. Aronu et al.: Effect of Talinum triangulare on haematology and serum biochemistry of layers

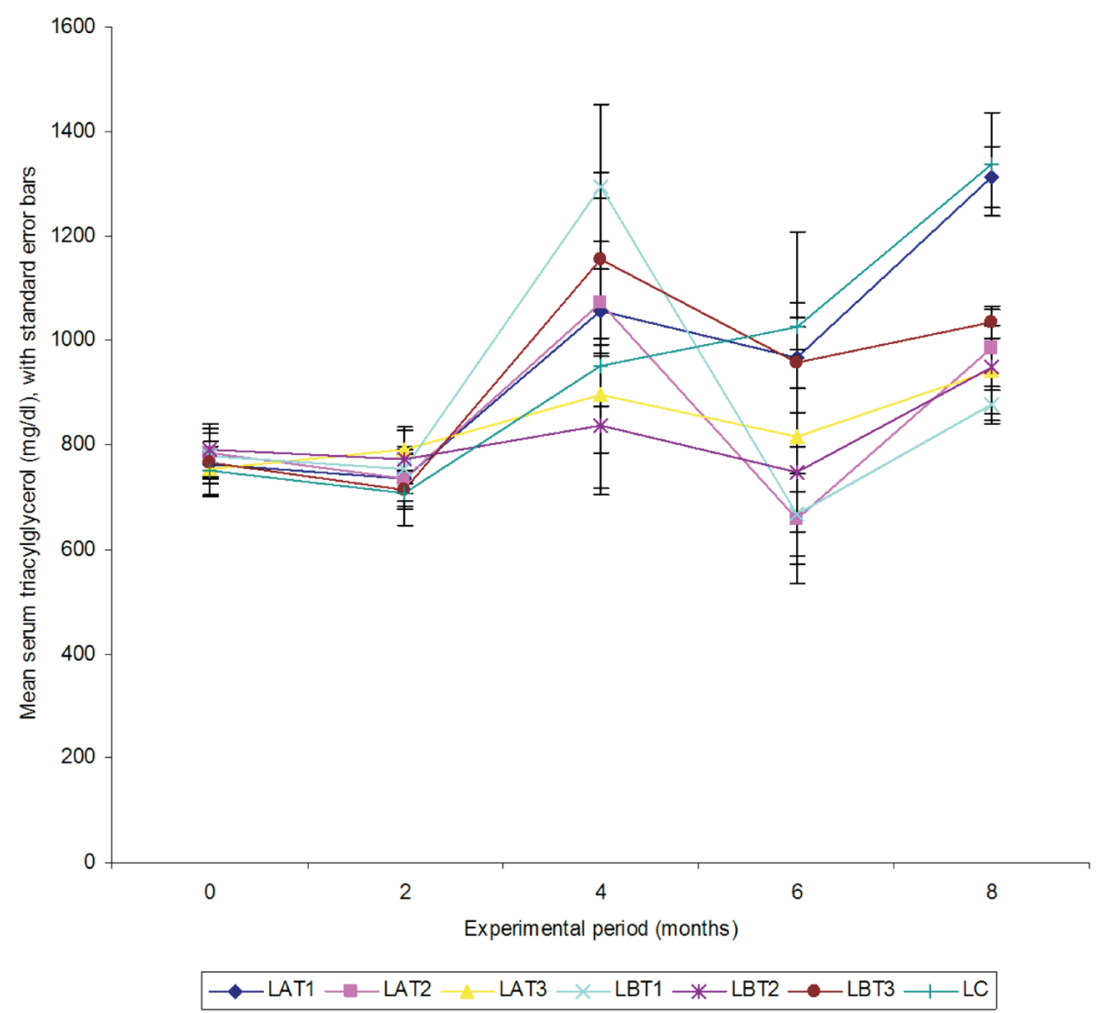

Fig. 6. The serum triacylglycerol levels of groups* of laying hens given varied doses of extracts of dried-pulverised and fresh Talinum triangulare in drinking water. * Groups and their treatments:

LAT1, LAT2 and LAT3 were given 62.5, 250 and $1000 \mathrm{mg} / \mathrm{L}$ of extract of dried-pulverised $T$. triangulare, respectively; LBT1, LBT2 and LBT3 were given 62.5, 250 and $1000 \mathrm{mg} / \mathrm{L}$ of extract of freshly harvested T. triangulare, respectively; while LC was the untreated control given plain drinking water only.

Serum triacylglycerol levels in all the groups of experimental birds also generally increased with age (Fig. 6). There were no significant differences $(\mathrm{P}>0.05)$ in the serum triacylglycerol levels of all the groups at months $0,2,4$, and 6 , but at month 8 , the serum triacylglycerol levels of the layers in groups $\mathrm{LAT}_{2}, \mathrm{LAT}_{3}, \mathrm{LBT}_{1}$, and $\mathrm{LBT}_{2}$ were significantly lower $(\mathrm{P}<0.05)$ than those of the other groups $\left(\mathrm{LAT}_{1}, \mathrm{LBT}_{3}\right.$, and LC) (Fig. 6). 


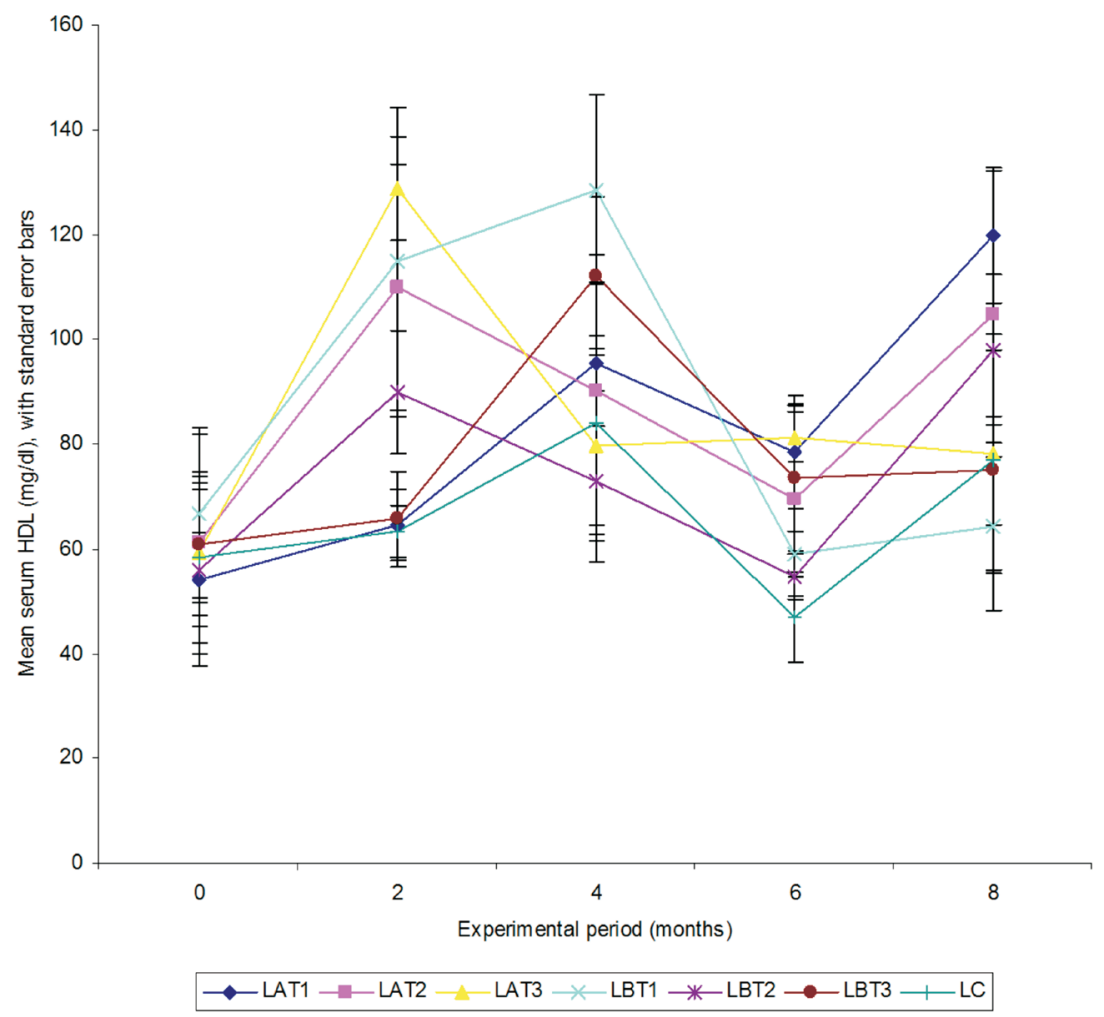

Fig. 7. The serum high density lipoprotein cholesterol (HDL-C) levels of groups* of laying hens given varied doses of extracts of dried-pulverised and fresh Talinum triangulare in drinking water.

* Groups and their treatments: LAT1, LAT2 and LAT3 were given 62.5, 250 and $1000 \mathrm{mg} / \mathrm{L}$ of extract of dried-pulverised T. triangulare, respectively; LBT1, LBT2 and LBT3 were given 62.5, 250 and $1000 \mathrm{mg} / \mathrm{L}$ of extract of freshly harvested T. triangulare, respectively; while LC was the untreated control given plain drinking water only.

No significant variations $(\mathrm{P}>0.05)$ were recorded for the serum HDL cholesterol levels of all the groups at month 0,4 , and 8 (Fig. 7). At month 2 however, the serum HDL-C of the birds in group $\mathrm{LAT}_{2} \mathrm{LAT}_{3}$, and $\mathrm{LBT}_{1}$ were significantly $(\mathrm{P}<0.05)$ higher than those of all the other groups, while at month 6 the serum HDL-C of the birds in all the treated groups $\left(\mathrm{LAT}_{1}, \mathrm{LAT}_{2}, \mathrm{LAT}_{3}, \mathrm{LBT}_{1}, \mathrm{LBT}_{2}\right.$, and $\left.\mathrm{LBT}_{3}\right)$ was significantly higher $(\mathrm{P}<0.05)$ than that of the LC control group (Fig. 7). 
C. J. Aronu et al.: Effect of Talinum triangulare on haematology and serum biochemistry of layers

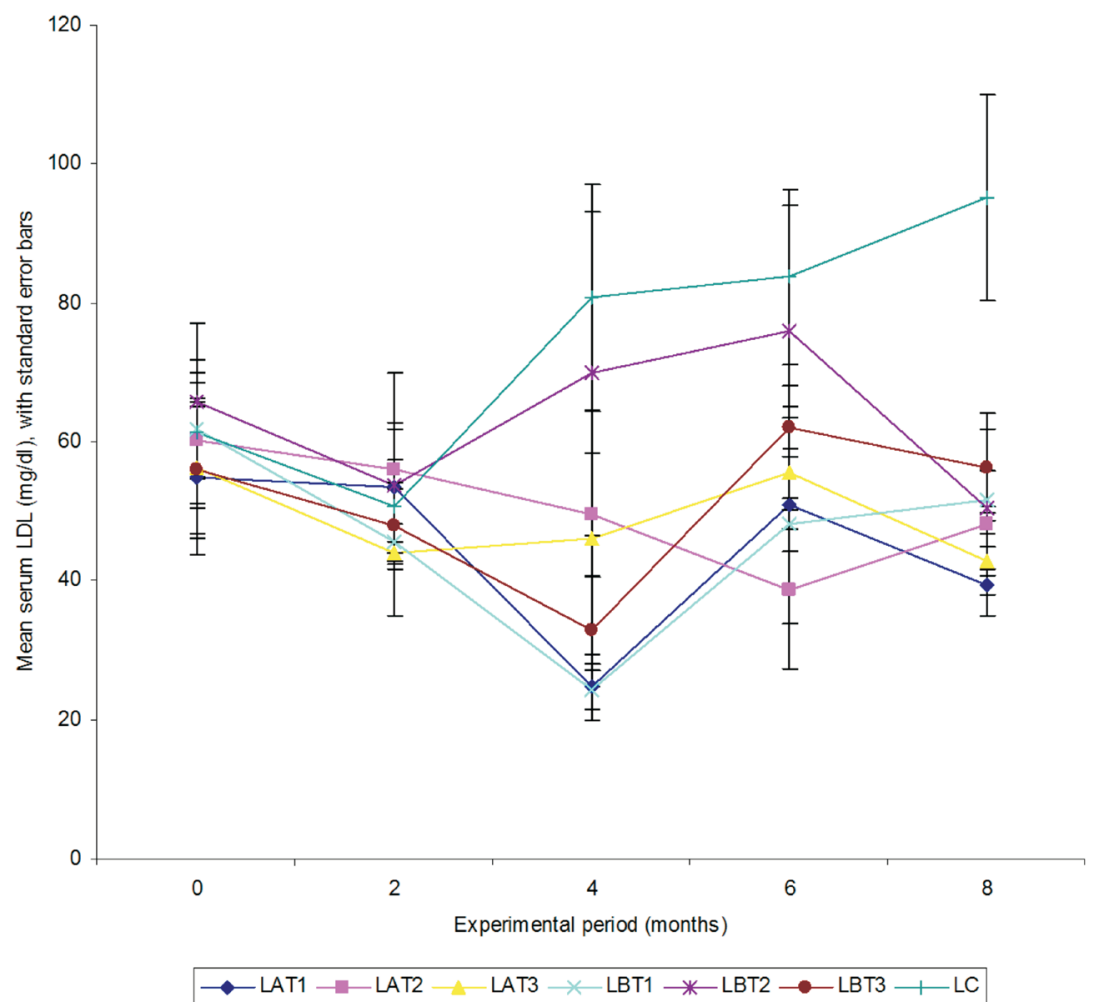

Fig. 8. The serum low density lipoprotein cholesterol (LDL-C) levels of groups* of laying hens given varied doses of extracts of dried-pulverised and fresh Talinum triangulare in drinking water.

* Groups and their treatments: LAT1, LAT2 and LAT3 were given 62.5, 250 and $1000 \mathrm{mg} / \mathrm{L}$ of extract of dried-pulverised T. triangulare, respectively; LBT1, LBT2 and LBT3 were given 62.5, 250 and $1000 \mathrm{mg} / \mathrm{L}$ of extract of freshly harvested T. triangulare, respectively; while LC was the untreated control given plain drinking water only.

The serum LDL-C levels of all the groups did not vary significantly $(\mathrm{P}>0.05)$ at Months 0 and 2, but at Months 4 and 8 of the experimental period, the serum LDL-C levels of all the treated groups were significantly lower $(\mathrm{P}<0.05)$ than that of the LC untreated control, while on Month 6, only the serum LDL-C levels of the layers in group $\mathrm{LAT}_{2}$ and $\mathrm{LBT}_{2}$ were significantly $(\mathrm{P}<0.05)$ lower than that of the LC untreated control (Fig. 8). 
C. J. Aronu et al.: Effect of Talinum triangulare on haematology and serum biochemistry of layers

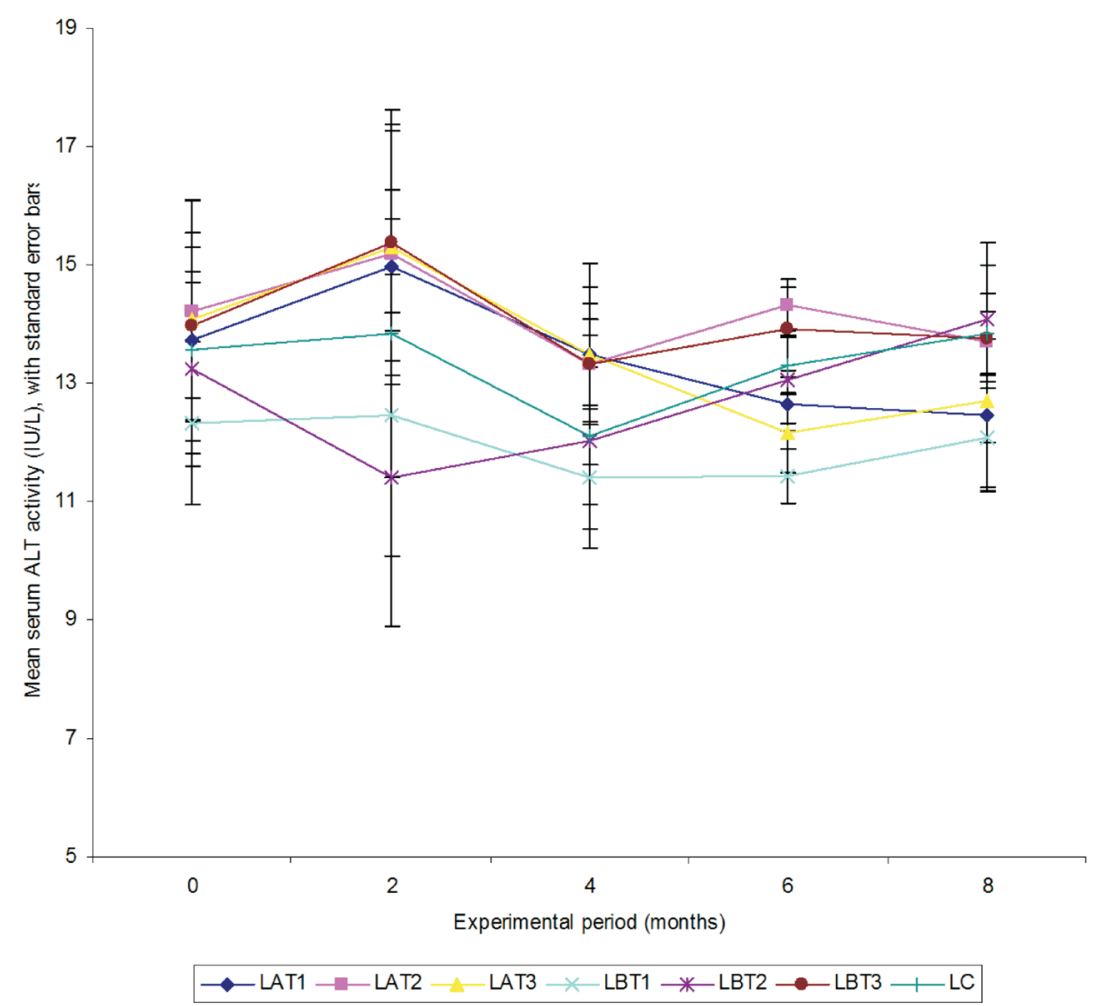

Fig. 9. The serum alanine aminotransferase (ALT) activity of groups* of laying hens given varied doses of extracts of dried-pulverised and fresh Talinum triangulare in drinking water. * Groups and their treatments: LAT1, LAT2 and LAT3 were given $62.5,250$ and $1000 \mathrm{mg} / \mathrm{L}$ of extract of dried-pulverised T. triangulare, respectively; LBT1, LBT2 and LBT3 were given 62.5, 250 and $1000 \mathrm{mg} / \mathrm{L}$ of extract of freshly harvested $T$. triangulare, respectively; while LC was the untreated control given plain drinking water only.

There were no significant variations $(\mathrm{P}>0.05)$ in serum ALT and AST activities or the serum total protein levels of all the groups (both treated and untreated) throughout the experimental period (Fig. 9, 10 and 11). 
C. J. Aronu et al.: Effect of Talinum triangulare on haematology and serum biochemistry of layers

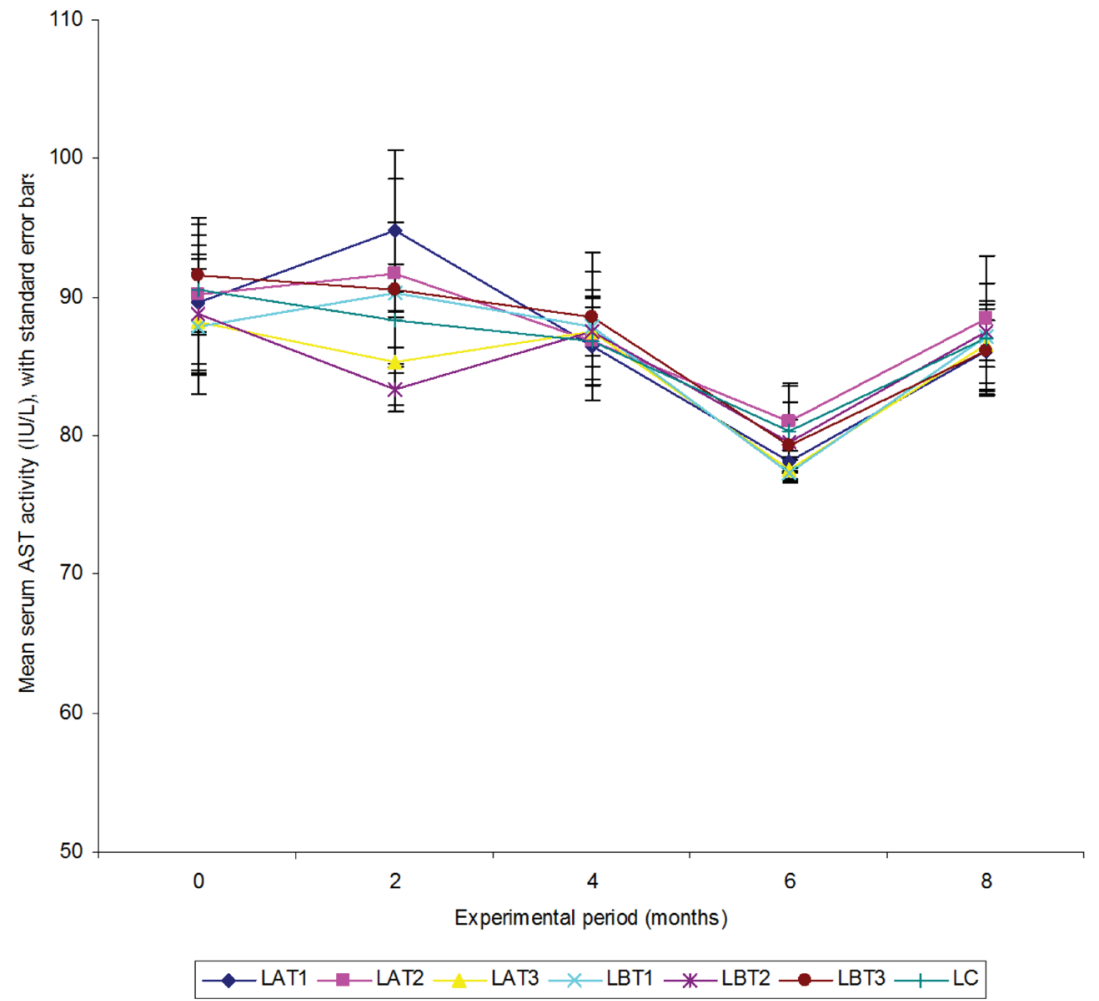

Fig. 10. The serum aspartate aminotransferase (ALT) activity of groups* of laying hens given varied doses of extracts of dried-pulverised and fresh Talinum triangulare in drinking water. * Groups and their treatments: LAT1, LAT2 and LAT3 were given $62.5,250$ and $1000 \mathrm{mg} / \mathrm{L}$ of extract of dried-pulverised T. triangulare, respectively; LBT1, LBT2 and LBT3 were given 62.5, 250 and $1000 \mathrm{mg} / \mathrm{L}$ of extract of freshly harvested T. triangulare, respectively; while LC was the untreated control given plain drinking water only. 


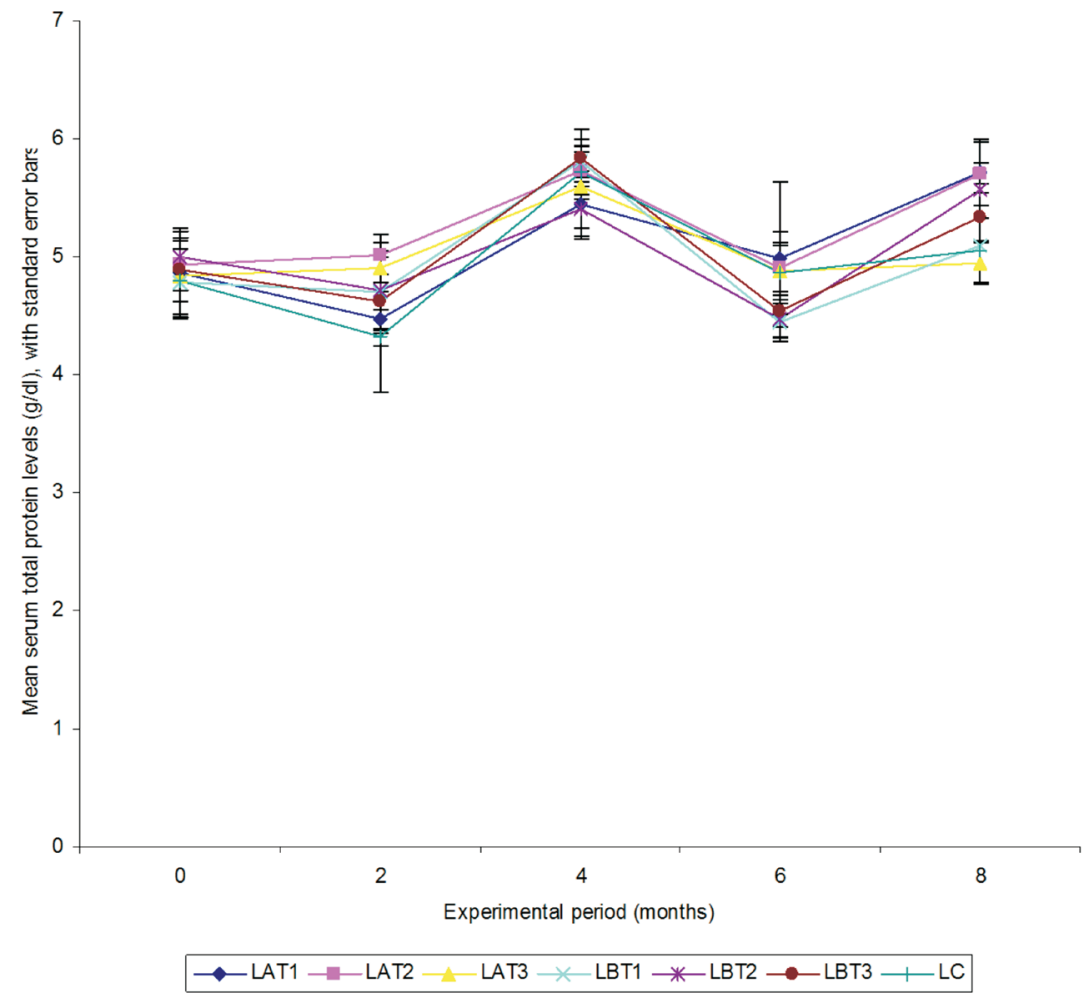

Fig. 11. The serum total protein (TP) levels of groups* of laying hens given varied doses of extracts of dried-pulverised and fresh Talinum triangulare in drinking water. * Groups and their treatments: LAT1, LAT2 and LAT3 were given $62.5,250$ and $1000 \mathrm{mg} / \mathrm{L}$ of extract of driedpulverised T. triangulare, respectively; LBT1, LBT2 and LBT3 were given 62.5, 250 and 1000 $\mathrm{mg} / \mathrm{L}$ of extract of freshly harvested $T$. triangulare, respectively; while LC was the untreated control given plain drinking water only.

\section{Discussion}

There was no adverse effect on the health status of the layers used for the study, as observed from the results of the hematology, serum enzymes, and total protein assays. This agrees with results from other researchers, such as EZEKWE et al. (2006), and suggests that the phytochemicals, such as tannins, saponins, alkaloids etc., present in $T$. triangulare occur in levels that are not toxic to birds at the dosages offered. This is also supported by reports by AJA et al. (2010), that showed the level of tannin in T. triangulare to be much lower than the five per cent reported to be toxic to animals. 


\section{J. Aronu et al.: Effect of Talinum triangulare on haematology and serum biochemistry of layers}

Generally, the untreated group (LC) recorded the highest levels of TChol, triacylglycerol and LDL concentrations. Treatment with aqueous extract, from either dried and pulverised, or freshly harvested T. triangulare therefore had positive modulatory effects on the lipid profile components of layers, which is an advantage for a healthier life and productivity.

The triacylglycerol concentration in the serum was reduced at high inclusion levels of dried T. triangulare $\left(\mathrm{LAT}_{3}\right)$ but a lower inclusion level of supplementation had little or no effect on triacylglycerol. Conversely, at a low dose inclusion level of supplementation with fresh $T$. triangulare $\left(\mathrm{LBT}_{1}\right)$ triacylglycerol was significantly reduced, whereas at a high dose $\left(\mathrm{LBT}_{3}\right)$ inclusion level the effect seems to reverse. This suggests that a nutrient or bioactive component of freshly harvested T. triangulare, which may be significantly reduced in the dry state (such as tocopherol and glycosides), was responsible for the reduction of triacylglycerol. Probably, at the higher inclusion level with the fresh sample, toxic factors began to precipitate which resulted in the reverse of the function observed. It is important to discover the differences between the two samples used (i.e. dried and fresh samples) in terms of their composition of nutrients and active agents. SAEID et al. (2010) reported lower triacylglyceride levels in laying hens fed with ginger. The elevated triacylglycerol level reported at the age of physiological puberty (4 months) in a previous study on growing pullets (yet to be published) was sustained with the commencement of laying, and further heightened with the establishment of laying and throughout the laying period.

It is important to observe the strategic times at which significant changes occurred in the parameters studied. First, at month two of treatment, HDL became significantly higher in the treated group than in the control. This coincides with the time egg laying was established in the pullets. At month four of treatment (34 weeks of age), and coinciding with the attainment of peak of egg production, major changes were observed such as significant reductions in total cholesterol level with $\mathrm{LAT}_{1}$ in comparison with control LC and LDL in the treated groups in comparison with the untreated control group LC.

The reduction in total cholesterol levels and LDL-C concentrations and the increase in HDL-C achieved with $T$. triangulare supplementation have the potential of making laying hens less susceptible to atherosclerosis and fat deposition on their organs, as seen in fatty liver obesity which has negative implications on health and egg production in layers.

Both preparations (dried-pulverised and fresh $T$. triangulare extracts) affected the lipid profile to various degrees and at different doses. However, the dried-pulverised sample had a better effect on HDL than the freshly harvested, and the highest dose was significantly better than the medium and the low doses. Both preparations affected the LDL 
similarly with the low doses giving results not significantly different from the medium and highest doses. Supplementation with $T$. triangulare had a profoundly positive effect on the lipid profile of layers, which appears more overtly at points of stress or increased demand for nutrients and the biochemical components of the pullet's physiology. This suggests that supplementation of layers' drinking water with $T$. triangulare may have anti-stress and immune boosting effects. This however needs to be investigated further.

\section{Conclusion}

Dietary supplementation with T. triangulare at the doses offered had no significant impact on the haematology, serum enzymes and total protein levels of layers used in the study. Treatment led to positive effects on lipid profile, which included lowering of serum total cholesterol, triacylglycerol, and LDL-C, and elevation of the serum HDL-C of some of the treated groups when compared to the untreated control. The extract from the driedpulverised sample at the highest dose $(1000 \mathrm{ml} / \mathrm{L})$ increased HDL-C and reduced LDL-C better than that from the freshly harvested sample. However, the extract from the freshly harvested sample reduced triacylglycerol at a low dose better than the dried at medium and high doses. The extract from the dried-pulverised sample administered at $1000 \mathrm{mg} / \mathrm{L}$ dose may be preferred over the freshly harvested sample.

\section{References}

AJA, P. M., A. N. C. OKAKA, P. N. ONU, U. A. IBIAM, A. J. URAKU (2010): Phytochemical composition of Talinum triangulare (waterleaf) leaves. Pak. J. Nutr. 9, 527-530.

AKACHUKU, C. O., M. A. O. FAWUSI (1995): Growth characteristics, yield and nutritional value of waterleaf, Talinum triangulare (Jacq) Willd in a semi-wild environment. Discov. Innovat. 7, 163-172.

ALBERS, J. J., G. R. WARNICK, M. C. CHEUNG (1978): Quantitation of high density lipoproteins. Lipids 13, 926-932.

DOI: $10.1007 / / \mathrm{BF} 02533878$

ALlAin, C. C., L. S. POON, C. S. CHAN, W. RICHMOND, P. C. FU (1974): Enzymatic determination of total serum cholesterol. Clin. Chem. 20, 470-475.

ANONYMOUS (2008): Rising food prices: causes and consequences. OECD, 1-9.

ANONYMOUS (2014): Poultry and nutrition and feed. Animal Production and Health division, FAO, Rome.

BUCCOLO, G., H. DAVID (1973): Quantitative determination of serum triglycerides by the use of enzyme. Clin. Chem. 19, 476.

CAMPBELL, J. Y. (1994): Inspecting the mechanism: an analytical approach to the Stochastic Growth Model. J. Monetary Econ. 33, 463-506. 
C. J. Aronu et al.: Effect of Talinum triangulare on haematology and serum biochemistry of layers

CHANDRA, K. S., D. GOGOI, K. H. GAUTAM, A. K. HANDIQUE (2016): Nutritive values of some non-conventional leafy vegetables and scarcity food plants of North East India. African J. Food Sci. 10, 340-343.

DOI: $10.5897 / A J F S 2016.1427$

EZEKWE, M. O., S. A. BESONG, P. E. IGBOKWE, E. I. EZEKWE (2006): Food compositions comprising waterleaf leaves and methods of using thereof United States Patent 7118771. Source: http://www.freepatentsonline.com/7118771.html

FRIEDEWALD, W. T., R. I. LEVY, D. S. FREDRICKSON (1972): Estimation of the concentration of low density lipoprotein cholesterol in plasma, without use of the preparative ultracentrifuge. Clin. Chem. 18, 499-502.

HIGGINS, T., E. BENTLER, B. T. DOUMAS (2003): Haemoglobin, iron and bilirubin Teitz, In: Fundamentals of Clin. Chem. $6^{\text {th }}$ ed. 28, 509-526.

IHEDIOHA, J. I., I. K. IDIKA, G. N. OGAMBA, C. J. A. AKAM (2008) Changes in the haematological values of avian blood samples stored at varying temperatures for a period of up to 72 hours. Comp. Clin. Pathol. 17, 73 - 79.

DOI:10.1007/s00580-008-0723-5

KWENINI, W. K, J., M. WOLLI, B. M. DZOMEKU (2011): Asssessing the nutritional values of some African indigenous green leafy vegetables in Ghana. J. Anim. Plant. Sci. 10, 1300-1305.

LUBRAN, M. M. (1978): The measurement of total serum proteins by the Biuret method. Ann. Clin. Lab. Sci. 8, 106-110.

MENGESHA, M. (2012): The issue of feed-food competition and chicken production for the demands of foods of animal origin. Asian J. Poult. Sci. 6, 31-43.

DOI: 10.3923/ajps.2012.31.43

OTTAH, A. A., ONUOHA, O. O. IGBOELI, M. EZEJA (2012): Antihyperglycemic effects of the methanol leaf extract of diaphananthebidens in normoglycemicandstreptozotocin - induced hyperglycaemic rats. Asian Pac. J. Trop. Med. 5, 192-196.

DOI:10.1016/S1995-7645(12)60023-6

PEM, D., R. JEEWON (2015): Fruit and vegetable intake: benefits and progress of nutrition education interventions - narrative review article. Iran J. Public Health, 44, 1309-1321.

REITMAN, S., S. FRANKEL (1957): A colorimetric method for determination of serum glutamic oxaloacetic and glutamic pyruvic transaminases. American J. Clin. Pathol. 28, 5.

SAEID, J. M., A. B. MOHAMED, M. A. AL-BADDY (2010): effect of aqueous extract of ginger (Zingiber officinale) on blood biochemistry parameters of broiler. Int. J. Poult. Sci. 9, 944-947.

SCHIPPERS, R. R. (2000): African indigenous vegetables. An overview of the cultivated species. Natural Resources Institute/ACP-EU Technical Centre for Agricultural and Rural Cooperation, Chatham, 214.

THRALL, M. A., M. G. WEISER (2002): Laboratory procedures for veterinary technicians. $4^{\text {th }}$ ed. Mosby-Year Book, Inc. 
C. J. Aronu et al.: Effect of Talinum triangulare on haematology and serum biochemistry of layers

WARNICK, G. R., R. H. KNOPP, V. FITZPATRICK, L. BRANSON (1990): Estimating lowdensity lipoprotein cholesterol by the Friedewald equation is adequate for classifying patients on the basis of nationally recommended cutpoints. Clin. Chem. 36, 15-19.

Received: 10 September 2017

Accepted: 11 June 2018

\begin{abstract}
ARONU, C. J., J. O. A. OKOYE, JOHN I. IHEDIOHA, B. N. MARIRE, S. M. ANIKA: Učinci vodenih ekstrakata sušenog praška ili svježeg oblika Talinum triangulare na hematološke i biokemijske pokazatelje u seruma nesilica. Vet. arhiv 88, 687-707, 2018.
\end{abstract}

\title{
SAŽETAK
}

Istražen je učinak stupnjevanih doza vodenog ekstrakta iz Talinum triangulare na hematološke i biokemijske pokazatelje u seruma kokoši nesilica. Za potrebe eksperimenta korišteno je 210 pilenki koje su nabavljene u dobi od 18 tjedana. Pilenke su nasumično podijeljene u 7 skupina (LAT1, LAT2, LAT3, LBT1, LBT2, LBT3 i LC). Svaka je skupina replicirana tri puta, a svaki je replikat uključivao smještaj 10 pilenki. Ekstrakt dobiven iz suhog praška T. triangulare davan je skupinama LAT1, LAT2 i LAT3 u vodi za piće, u dozama od 62,5, 250 i $1000 \mathrm{mg} / \mathrm{L}$. Ekstrakti dobiveni iz svježe ubrane biljke Talinum triangulare davani su skupinama LBT1, LBT2 i LBT3, u dozama od 62,5, 250 i $1000 \mathrm{mg} / \mathrm{L}$, također u pitkoj vodi. Pilenke u skupini LC služile su kao kontrola koja nije konzumirala nikakav ekstrakt. Biokemijski i hematološki pokazatelji u serumu određivani su standardnim postupcima, u dvomjesečnim intervalima, tijekom 8 mjeseci davanja ekstrakata. Rezultati su pokazali da među istraživanim skupinama nema signifikantnih razlika $(\mathrm{P}>0,05) \mathrm{u}$ hematokritu, broju eritrocita, koncentraciji hemoglobina, ukupnim broju leukocita, aktivnostima serumske alanin-aminotransferaze i aspartat-aminotransteraze te u ukupnim proteinima. Tijekom eksperimenta, posebice u 4. i 8. mjesecu, u skupini LAT3 u odnosu na ostale skupine koncentracija lipoproteina visoke gustoće u serumu bila je viša, a koncentracija lipoproteina niske gustoće u serumu niža $(\mathrm{P}<0,05)$. Zaključeno je da davanje $T$. triangulare nije imalo štetan utjecaj na zdravlje i proizvodni status nesilica, dok je pozitivan učinak utvrđen za njihov profil masnoća u serumu. Zbog svojih antilipemijskih svojstava osušeni prašak Talinum triangulare preporučuje se kao fitobiotički dodatak za zdrav proizvodni život kokoši nesilica, u dozi od $1000 \mathrm{mg} / \mathrm{L}$.

Ključne riječi: Talinum triangulare; hematologija; biokemija seruma; zdravlje; fitobiotik; kokoši nesilice 
